\title{
ESTIMATION OF SECOND SEASON MAIZE YIELD LOSS BY THE SPATIAL VARIABILITY OF THE SOIL PHYSICAL-WATER PROPERTIES
}

\author{
ESTIMATIVA DA PERDA DE PRODUTIVIDADE DO MILHO SEGUNDA SAFRA \\ PELA VARIABILIDADE ESPACIAL DAS CARACTERÍSTICAS FÍSICO-HÍDRICAS \\ DO SOLO
}

\begin{abstract}
Luiz Ricardo SOBENKO ${ }^{1}$; Robson André ARMINDO ${ }^{2}$; Wagner WOLFF ${ }^{\mathbf{1}}$; Jéfferson de Oliveira COSTA ${ }^{1}$; Jarbas Honório de MIRANDA ${ }^{1}$; Sérgio Nascimento DUARTE ${ }^{1}$

1. Biosystems Engineering Dept., University of São Paulo - USP, College of Agriculture "Luiz de Queiroz" (ESALQ), Piracicaba, SP, Brazil. luizsobenko@ usp.br; 2. Soils and Agricultural Engineering Dept., Federal University of Paraná - UFPR, Curitiba, PR, Brazil.
\end{abstract}

\begin{abstract}
Irrigation systems are still traditionally dimensioned and managed considering that the cultivated area is homogeneous, thereby not taking into account the spatial variability of soil physical and hydraulic parameters, potentially limiting productivity. The aim of this work was to estimate the yield losses of second season maize crops when comparing the application of constant and variable complementary irrigation depths along the area, in scenarios with distinct rainfall indices, for an irrigated area in the state of Mato Grosso, Brazil. Data of the soil parameters bulk density $\left(\rho_{\mathrm{b}}\right)$ and available water capacity (AWC) were analysed and maps of spatial variability were generated using geostatistical tools. In the sequence, water balance for the average values of $\rho_{\mathrm{b}}$ and AWC and individual water balances for each pixel generated in the interpolations were determined, allowing the estimation of production losses due to the application of water depths. The water demand of the second season maize was estimated with precision for the three scenarios studied. Traditional irrigation management resulted in deficit areas and excessive depths up to $54 \mathrm{~mm}$ for both cases, leading to a reduction in productivity of up to $12.5 \%$.
\end{abstract}

KEYWORDS: Geostatistical. Precision irrigation. Zea mays L.

\section{INTRODUCTION}

Brazil is the third largest producer of maize (Zea mays L.) in the world, with an average yield of around five tons per hectare for second season growth (National Supply Company - CONAB, 2018). However, this yield is not satisfactory considering the productive potential of the crop, which can reach $16 \mathrm{Mg} \mathrm{ha}^{-1}$ (COELHO et al., 2003).

Harvest oscillations and low yields are closely related to the amount of water available in the soil, especially in the critical periods of crop growing, reaching from the pest control to the onset of grain filling (BERGAMASCHI et al., 2004; ANDRIOLLI; SENTELHAS, 2009). In this phase, the crop is extremely sensitive to water deficit, and the productive capacity cannot recover optimally (BERGAMASCHI et al., 2006).

Therefore, the adoption of practices to ensure adequate water supply during the critical growth periods, such as orientation by agricultural zoning, seeding scheduling, and irrigation, guarantee better yields (BERGAMASCHI et al., 2004; MARIN et al., 2016). In terms of irrigation techniques, the systems are still dimensioned and managed considering that the area is homogeneous, neglecting the spatial variability of the physical and hydraulic soil parameters, which results in a relatively constant irrigation depth throughout the area.

Analysis of the variability of soil attributes by geostatistical techniques is important for the precise management of the agricultural areas, thereby minimising the effects of variability o crop production. The soil parameters as density and texture are directly related to the soil characteristics to retain and available water and, consequently, to plant root development (SOARES et al., 2012).

In this context, precision irrigation emerges as a possible solution, since it addresses the spatiotemporal heterogeneity in the field, allowing the application of water at variable rates and thereby ensuring correct water quantities at the appropriate time and place, resulting in optimised use of water and other environmental resources and increased crop productivity (KRANZ et al., 2012; HAGHVERDI et al., 2016).

In this sense, technologies have been developed to apply variable water rates throughout the field, which requires the determination of zones with different irrigation management strategies to minimise water losses and maintain production levels (CERESOLI et al., 2016). Armindo et al. (2011) developed a prototype sprinkler that applies water at a variable rate; its flow is controlled by the rotation of a conical tip rod that limits the area of 
the nozzle. Using linear programming, Haghverdi et al. (2015) developed and evaluated a model to establish zone irrigation management for central pivot irrigation systems based on satellite data, the apparent electrical conductivity of soil, yield data and available soil water.

Thus, considering the possibility of precision irrigation becoming a reality, this work aimed to estimate yield losses of second season maize when comparing the application of mean (constant) and precision (variable along the area) water depths, in scenarios with distinct precipitation indices, for an irrigated area in Brazil, Mato Grosso State.

\section{MATERIAL AND METHODS}

The work was carried out at Piva Farm, located in Sorriso, Mato Grosso State (latitude $12^{\circ}$
13 'S, longitude $55^{\circ} 39^{\prime} \mathrm{W}, 355 \mathrm{~m}$ a.s.l.). According to Köppen's classification (1931), the local climate is defined as tropical (Aw), characterised by a welldefined dry season in winter, between May and August.

The study site covered an area of 10 ha, and 33 sampling points with a spacing of $50 \mathrm{~m}$ were established in the field, using a Garmin 76CSX GPS device (Figure 1). Soil samples were collected in three replicates to determine bulk density $\left(\rho_{\mathrm{b}}\right)$ and texture; soil analyses were performed at the Soil Physics Laboratory, Department of Soils and Agricultural Engineering, Federal University of Paraná, as fully described by Ceresoli et al. (2016).

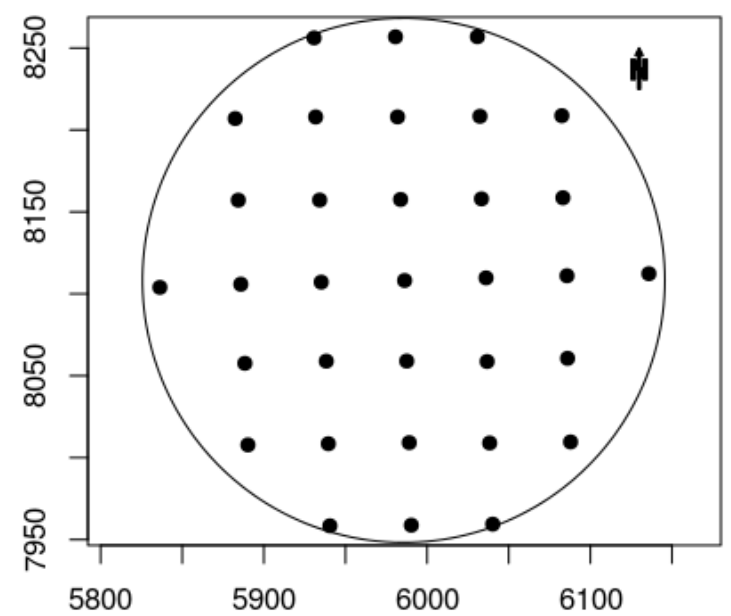

Figure 1. Grid sample for determination of bulk density and soil texture - UTM zone 21, datum SIRGAS 2000.

The soil water retention curve parameters were predicted using Rosetta (SCHAAP et al., 2001), from the data of $\rho_{\mathrm{b}}$ and texture, within the HYDRUS model package (SIMUNEK et al., 2005). With the parameters of the retention curves, water content at field capacity $\left(\theta_{\mathrm{cc}}\right)$ could be determined to assume that it coincides with the moment when the internal drainage rate of the soil decreases to a negligible value (Eq. 1) (ANDRADE; STONE, 2011). Therefore, the water content at the permanent wilting point $\left(\theta_{\mathrm{pmp}}\right)$ was determined via the Van Genuchten model (1980), using a matric head of $15,000 \mathrm{hPa}$ (Eq. 2).

$$
\begin{aligned}
& \theta_{c c}=\theta_{r}+\left(\theta_{s}-\theta_{r}\right)\left(p^{\left(\frac{1.5 n+0.5}{0.5-2.5 n}\right)}\right)^{\frac{1-n}{1.5 n+0.5}} \\
& \theta=\theta_{r}+\left(\theta_{s}-\theta_{r}\right) /\left[1+\left(\alpha\left|\psi_{m}\right|\right)^{n}\right]^{1-1 / n}
\end{aligned}
$$

$\theta_{\mathrm{cc}}-$ water content at field capacity $\left(\mathrm{cm}^{3} \mathrm{~cm}^{-3}\right) ; \theta_{\mathrm{r}}$ and $\theta_{\mathrm{s}}-$ residual and saturation water contents $\left(\mathrm{cm}^{3} \mathrm{~cm}^{-3}\right)$, respectively; $\mathrm{p}$ - relative drainage rate $(0.01) ; \mathrm{n}$ and $\alpha\left(\mathrm{cm}^{-1}\right)$ model fitting parameters; and $\psi_{\mathrm{m}}$ - soil water matric potential $(\mathrm{cm})$.

Thus, the available soil water capacity (AWC) was calculated by the product of the difference between $\theta_{\mathrm{cc}}$ and $\theta_{\mathrm{pmp}}$, and the effective depth of the maize $(\mathrm{z})$ root system varied from 0.05 to $0.4 \mathrm{~m}$, depending on the plant development stage.

Based on the assumptions described by Diggle and Ribeiro Jr. (2007), it was considered that a geostatistical model, described by a random and spatially correlated component, associated with a set of observations $(\mathrm{Zxi}, \ldots, \mathrm{Zxn})$, is given by the relation expressed in Equation 3:

$Z_{\mathrm{xi}}=\mu_{\mathrm{xi}}+\mathrm{S}_{\mathrm{xi}}+\varepsilon_{\mathrm{xi}}$

where:

$Z_{\mathrm{xi}}$ - value of the variable to be estimated at xi location; $\mu_{\mathrm{xi}}-$ deterministic component, associated to a constant average or to 
a function that models the average, called the spatial trend model; $S_{x i}-$ spatially correlated random component; and $\varepsilon_{\mathrm{xi}}-$ model residue.

Spatial analyses of AWC and $\rho_{\mathrm{b}}$ were performed as follows: I) deterministic component $\left(\mu_{x i}\right)$ and removal of possible spatial trends: linear and quadratic regression models were tested between covariates related to $\mathrm{AWC}$ and $\rho_{\mathrm{b}}$ (latitude, longitude and altitude of the sampling points). The best model was selected according to the Bayesian information criterion (BIC) (KONISHI; KITAGAWA, 2008). II) random component $\left(S_{x i}\right)$ : once the best spatial trend model was fixed, the functions of exponential (exp), spherical (sph), circular (circ), Gaussian (gaus) and Matérn, with kappa parameters 1.5 (M1.5), 2.5 (M2.5) and 3.5 (M3.5), were tested. As in the $\mu_{\mathrm{xi}}$ model, BIC was used to select the best correlation function.

After selection of the geostatistical model, the spatial prediction was performed using the ordinary kriging interpolator (CRESSIE, 1988). The software R (CORE TEAM, 2014) and the geoR package (RIBEIRO JR; DIGGLE, 2001) were used for the analysis.

To compare irrigation managements with constant and variable depths, the daily water balance of the second season maize crop was first performed for the mean values of $\rho_{b}$ and AWC, assuming that the entire area was homogeneous. In sequence, individual water balances were made for each pixel generated by the interpolations of $\rho_{b}$ and AWC to estimate the irrigation depths and quantify the water requirement of the crop along the whole cycle, considering the spatial variability of these parameters.

This procedure was performed for three scenarios, represented by years with different rainfall indices during the cropping season (January to June). The scenarios were classified as medium $(1,167 \mathrm{~mm})$, dry $(761 \mathrm{~mm})$ and wet $(1,411 \mathrm{~mm})$. The meteorological data used is part of a historical series of 30 years of an National Institute of Meteorology (INMET) meteorological station, located in Sinop, Mato Grosso State.

Estimation of reference evapotranspiration (ETo) was performed using the standard PenmanMonteith method and, consequently, crop evapotranspiration (ETc) was calculated by correcting ETo by the crop coefficient $(\mathrm{Kc})$. The values of Kc, recommended by Allen et al. (2006), were as follows: initial stage - 0.30 ; vegetative stage - 0.30 to 1.20 ; production stage - 1.20 ; maturation stage - 1.20 to 0.35 ; harvesting stage - 0.35. The daily increments of $\mathrm{Kc}$ values and the effective depth of the root system (up to a maximum of 0.4 $\mathrm{m}$ ) were simulated according to the days of each stage. The soil water depletion factor stipulated was 0.7 .

To determine yield losses when comparing irrigation management by medium and variable depths, the linear water-crop production function of Doorenbos and Kassam (1994) (Eq.4) was used. The crop sensitivity index (Ky) values for water deficit were those recommended by Andriolli and Sentelhas (2009).

$$
\mathrm{Yr}=\mathrm{Yp} \prod_{\mathrm{i}=1}^{5}\left[1-\mathrm{Ky}_{\mathrm{i}}\left(1-\frac{\mathrm{ETr}_{\mathrm{i}}}{\mathrm{ETp}_{\mathrm{i}}}\right)\right]
$$

where:

$\mathrm{Yr}$ - actual yield $\left(\mathrm{kg} \mathrm{ha}^{-1}\right) ; \mathrm{Yp}$ - potential yield $\left(\mathrm{kg} \mathrm{ha}^{-1}\right) ; \mathrm{Ky}-$ crop sensitivity index to water deficit (dimensionless); ETr real evapotranspiration $\left(\mathrm{mm} \mathrm{d}^{-1}\right) ;$ ETp $\quad-$ potential evapotranspiration $\left(\mathrm{mm} \mathrm{d}^{-1}\right) ; \mathrm{i}$ - five stages of the phenological cycle.

\section{RESULTS AND DISCUSSION}

Table 1 shows the summary results of the properties bulk density $\left(\rho_{\mathrm{b}}\right)$ and available water capacity (AWC). The mean and median values for both variables were close to each other and the data were normally distributed.

Table 1. Descriptive statistics of bulk density $\left(\rho_{\mathrm{b}}, \mathrm{kg} \mathrm{m}^{-3}\right)$ and available water capacity (AWC, mm)

\begin{tabular}{llllllll}
\hline & Mean & Med & Min & Max & $\sigma$ & $\lambda$ & $\lambda_{(95 \%)}$ \\
\hline$\rho_{\mathrm{b}}$ & $1,347.2109$ & $1,362.5704$ & 992.9902 & $1,689.3138$ & 0.1441 & 1.5 & $-1-4$ \\
AWD & 96.4264 & 96.8971 & 90.6101 & 100.0668 & 2.7336 & 10.0 & $-4-30$ \\
\hline
\end{tabular}

Med - median; Min - minimum; Max - maximum; $\sigma$ - standard deviation; $\lambda$ - box-cox; $\lambda_{(95 \%)}$ - box-cox with a confidence interval of $95 \%$.

Although the values of the parameter $\lambda$ of the Box and Cox (1964) family functions of data transformations presented different values of the unit, considering the maximum log-likelihood $(\lambda)$ for the $95 \%$ confidence interval $(\lambda 95 \%)$, the value was within this range. Thus, data did not require normalisation for geostatistical modeling and spatial prediction (Table 1).

Table 2 shows the models that guaranteed the spatial stationarity, therefore being the models that best represented the deterministic component $\left(\mu_{\mathrm{xi}}\right)$ of the geostatistical model and, consequently, removed spatial trends. For $\rho_{\mathrm{b}}$, it was not necessary 
to use a more complex model to remove tendencies, since the model with the constant average presented the lowest value of BIC. On the other hand, for AWC, there were trends in the north-south direction, which were removed by the model that considered latitude as an independent variable (Table 2).

Table 1. Evaluation of the spatial trend by the Bayesian information criterion (BIC), considering the exponential covariance function.

\begin{tabular}{lll}
\hline \multicolumn{2}{c}{ Model } & BIC \\
\hline$\rho_{\mathrm{b}}$ & $\mu_{\mathrm{xi}}=\beta_{0}$ & -21.25 \\
AWC & $\mu_{\mathrm{xi}}=\beta_{0}+\beta_{1} \mathrm{Y}$ & 136.34 \\
\hline
\end{tabular}

$\mu_{\mathrm{xi}}-$ deterministic component of the geostatistical model; $\beta_{\mathrm{n}}$ - parameters of the models; $\mathrm{Y}$ - latitude (km).

In Table 3 shows the selection of the function that best fits the random component $\left(S_{\mathrm{xi}}\right)$ and, consequently, spatially predicts $\rho_{\mathrm{b}}$ and AWC.
Thus, by the criterion of the lowest observed value of BIC, the spherical and circular functions presented the best fit for $\rho_{\mathrm{b}}$ and AWC, respectively.

Table 3. Evaluation of the correlation functions by the Bayesian information criterion (BIC), considering the selected trend models.

\begin{tabular}{llllllll}
\hline & Exp & Gauss & Sph & Circ & M1.5 & M2.5 & M3.5 \\
\hline$\rho_{\mathrm{b}}$ & -21.25 & -21.34 & $-21.47^{*}$ & -20.57 & -21.35 & -21.32 & -21.39 \\
AWC & 136.34 & 136.36 & 136.11 & $136.02 *$ & 136.32 & 136.36 & 136.29 \\
\hline
\end{tabular}

* - best correlation function; exponential correlation function - Exp; Gaussian correlation function - Gauss; spherical correlation function - Esf; circular correlation function - Circ; Matérn correlation function $\kappa=1.5-$ M1.5; Matérn correlation function $\kappa=2.5-$ M2.5 and Matérn correlation function $\kappa=3.5-\mathrm{M} 3.5$.

The need for normalisation of data was not verified (box-cox transformation parameter, $\lambda=1$ ). Therefore, spatial trend models and covariance functions were chosen and, using the maximum likelihood method, we estimated directly all the parameters of the geostatistical models. Among these, the $\beta$ parameters that match the mean can be checked in Table 4 and represent $\mu_{\mathrm{xi}}$; the parameters of the covariance functions, $\sigma^{2}$ and $\phi$, represent $S_{x i}$, and the parameter $\tau$ corresponds to the residual variance $\left(\varepsilon_{\mathrm{xi}}\right)$.

Table 4. Estimation of the parameters of the geostatistical model.

\begin{tabular}{llllll}
\hline & $\beta_{0}$ & $\beta_{1}$ & $\tau^{2}$ & $\sigma^{2}$ & $\phi(\mathrm{km})$ \\
\hline$\rho_{\mathrm{b}}$ & 1.35 & - & 0.019 & 0.001 & 48.38 \\
$\mathrm{AWC}$ & 302.36 & -0.025 & 1.81 & 0.36 & 144.24 \\
\hline
\end{tabular}

Deterministic component parameters $\left(\mu_{\mathrm{xi}}\right)-\beta_{\mathrm{n}}$; random component parameters $\left(\mathrm{S}_{\mathrm{xi}}\right)-\tau^{2}, \sigma^{2}$ e $\phi$.

Among the parameters of the correlation functions, which represent the random component of the geostatistical model, the parameter $\phi$ (range) stands out, the distance at which the samples are spatially correlated. The AWC had a greater "range" compared to $\rho_{\mathrm{b}}$. Thus, at greater distances, the samples present spatial dependence.

The $\rho_{\mathrm{b}}$ presented classes between 900 and $1,670 \mathrm{~kg} \mathrm{~m}^{-3}$ (Figure 2A). These values are typical of soils classified as sandy loam, such as the soil of the study area Ceresoli et al. (2016). In certain zones, the values of $\rho_{b}$ obtained were within the range of critical values stipulated by Reichert et al. (2003). For this type of soil, these critical values ranged from 1,600 to $1,700 \mathrm{~kg} \mathrm{~m}^{-3}$, which may be a limiting factor for crop development.

The retention curve parameters predicted by the Rosetta tool allowed the determination of the upper and lower limits of available water and, consequently, of the water balance for the second season maize in each pixel. The AWC map presented classes ranging from 93.52 to $97.75 \mathrm{~mm}$, showing that the values increased for the lower part of the area. For areas with lower levels, where sand content was higher than $75 \%$, texture also influenced soil water storage capacity (PREVEDELLO; ARMINDO, 2015). 
(A)

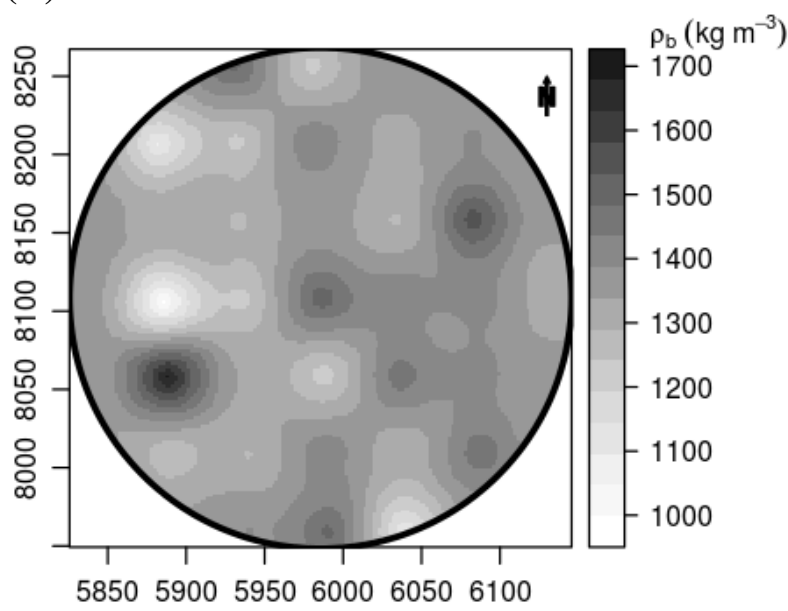

(B)

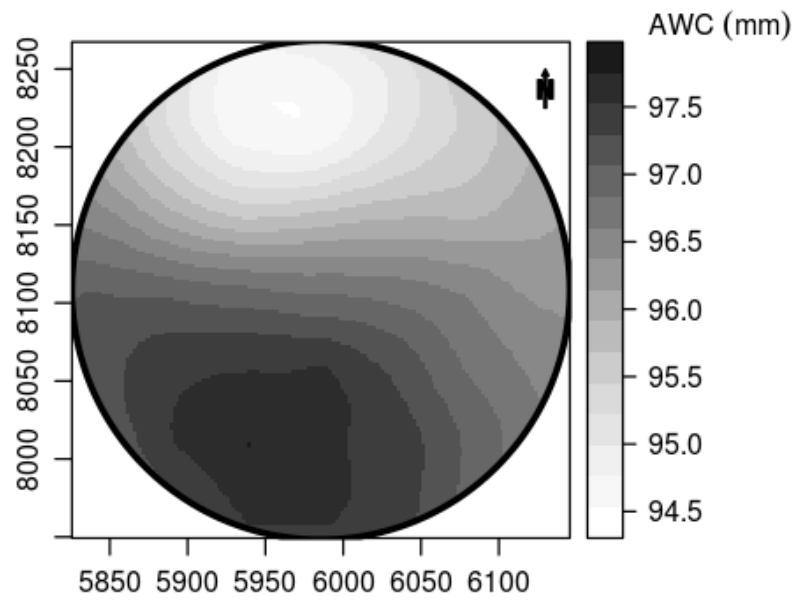

Figure 2. Thematic maps of bulk density (A) and available water capacity data (B).

Figure 3 shows the water balance maps for the three-year period, considering the spatial variability of the soil, showing that the highest irrigation depths were necessary at the points where $\rho_{\mathrm{b}}$ was higher. In Figure 3, it can be seen that for the medium scenario, the water demand of the crop ranged from 758.65 to $865.95 \mathrm{~mm}$. For the dry and wet scenarios, it ranged from 767.73 to $870.60 \mathrm{~mm}$ and 702.44 to $798.59 \mathrm{~mm}$, respectively.
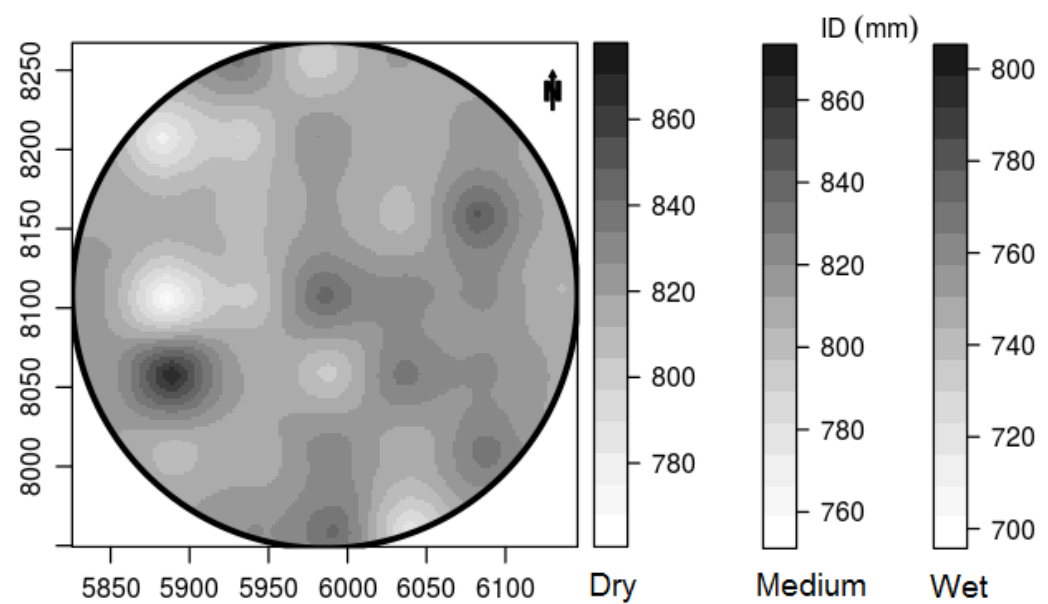

Figure 3. Thematic maps showing water requirement $(\mathrm{mm})$ throughout the second season maize whole cycle, studied scenarios.

In studies carried out by Comunello (2016), a potential water consumption of $475 \mathrm{~mm}$ second season maize was observed when the author evaluated a lysimetric set to determine the water demand of the crop in Dourados, Mato Grosso do Sul State. In the same locality, applying supplementay irrigation depths in maize, Pegorare et al. (2009) observed that a $510 \mathrm{~mm}$ depth increased productivity by up to $130 \%$ in relation to the rainfed growth. To test for differences between the water demands of the corn crop in Bagé, Santa Maria and Uruguaiana, Rio Grande do Sul State, at different growing seasons, Kopp et al. (2015) verified demands in the order of 531 to $735 \mathrm{~mm}$. Souza et al. (2012), in Seropédica, Rio de Janeiro State, observed that, after selection of different cropping systems, "Eldorado" maize cultivar had a total water consumption of $394.1 \mathrm{~mm}$.

When irrigation management was carried out through the water balance with mean values of $\rho_{\mathrm{b}}$ and AWC, the second season maize presented estimated water demand values along the whole cycle of $811.99,818.87$ and $749.88 \mathrm{~mm}$ for the medium, dry and wet scenarios, respectively. Thus, the application of an average depth was simulated throughout the area and considered to be homogeneous.

For the three scenarios, the traditional irrigation management provided the application of deficit and excessive depths in points of the area up 
to $53.15 \mathrm{~mm}$ for both cases (Figure 4). According to Armindo et al. (2011), excess depths may lead to leaching of nutrients and soil particles, thereby changing soil physical and chemical characteristics, in addition to causing water and energy losses.

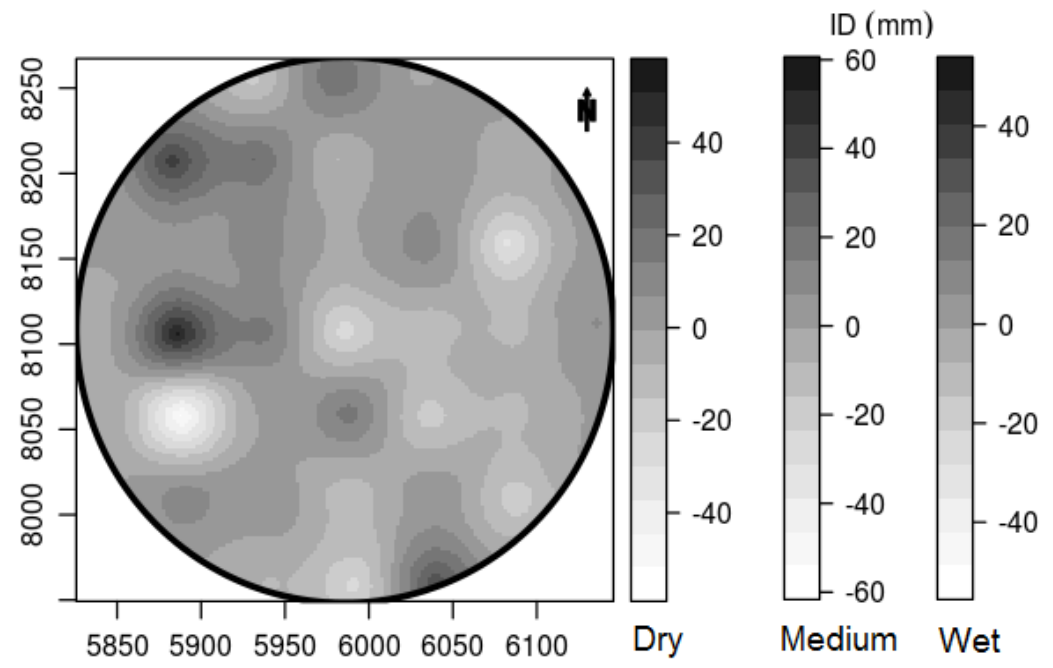

Figure 4. Thematic maps showing the defict and excessive ( $\mathrm{mm}$ ) depths derived from the comparison of irrigation management with medium and variable depths throughout the second season maize whole cycle, for the studied scenarios.

In the production stage of the crop, where water deficit sensitivity is higher and makes the losses irreversible, in some points, water application up to $30 \mathrm{~mm}$ less than the crop would be required in the three scenarios.
Applying irrigation to an average depth results in insufficient water supply at certain points, leading to water stress and, consequently, reduced productivity (Figure 5). For the three scenarios and at the points with water restriction, reductions in productivity ranged from 1.80 to $12.5 \%$.

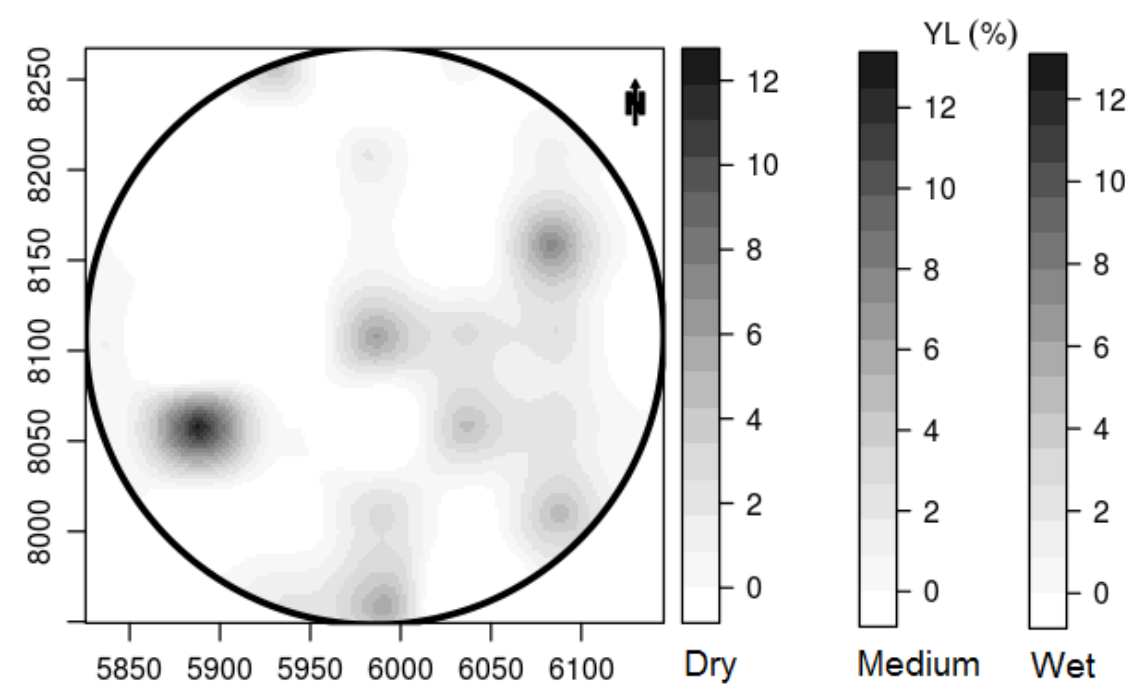

Figure 5. Thematic map of yield loss (\%) with irrigation management based on the mean depth throughout the second season maize whole cycle, for the studied scenarios.

Bergamaschi et al. (2004) studied the relationship between water supply and grain yield in maize crops and observed yields lower than $70 \%$ under water deficit conditions during the critical period of the crop. The authors explain that a short drought at this stage leads to delayed or even absent spike emission. Pegorare et al. (2009) also points out that the maize crop is very sensitive to the water deficit during these stages, requiring a strict control in the frequency of irrigation.

When evaluating maize cultivars yields under conditions of severe water restriction in Dois 
Vizinhos, Paraná State, Silva et al. (2012) observed a strong impact on productivity, obtaining values ranging from 0.66 to $4.73 \mathrm{Mg} \mathrm{ha}^{-1}$.

In areas where $\rho_{\mathrm{b}}$ was greater than $1,550 \mathrm{~kg}$ $\mathrm{m}^{-3}$, the greatest losses in production occurred when irrigation management was simulated by the application of constant depths. Crops may be negatively affected by low soil porosity and drainage as well as by mechanical impediments to root growth. Therefore, evaluating spatial variability is crucial for designing and managing irrigation systems.

Based on our results, we suggest that irrigated sectors with better soil physical conditions provide higher amounts of water to the plants, thereby increasing yields.

\section{CONCLUSIONS}

Irrigation management based on soil physical and water data suggests differences of depth between areas with deficit and excessive depths, reaching up to $54 \mathrm{~mm}$ for the whole cycle of second season maize; and

Application of mean water depth results in deficit areas and yield loss of up to $12.5 \%$, stressing the need for variable irrigation rates to ensure adequate water supply and rational use of water.

RESUMO: Os sistemas de irrigação ainda são tradicionalmente dimensionados e manejados considerando que a área cultivada seja homogênea, não se levando em conta a variabilidade espacial dos parâmetros físico-hídricos do solo, podendo ser esta um fator limitante à produtividade. Assim, este trabalho teve por objetivo estimar as perdas de produtividade da cultura do milho "safrinha" ao comparar a aplicação de lâminas complementares constantes e variáveis ao longo da área, em cenários com índices de precipitação pluvial distintos, para uma área irrigada no estado do Mato Grosso. Dados dos parâmetros densidade do solo $\left(\rho_{\mathrm{s}}\right)$ e capacidade de água disponível (CAD) foram analisados, e mapas de variabilidade espacial foram gerados por meio de ferramentas de geoestatística. Em sequência, realizou-se o balanço hídrico para os valores médios de $\rho_{\mathrm{s}}$ e CAD, e balanços hídricos individuais para cada pixel gerado nas interpolações, permitindo estimar as perdas de produção por conta da aplicação de lâminas deficitárias. A demanda hídrica da cultura do milho "safrinha" foi estimada com precisão para os três cenários estudados. O manejo da irrigação tradicional proporcionou a aplicação de lâminas deficitárias e excessivas em até $54 \mathrm{~mm}$ para os dois casos, o que acarretou em reduções de produtividade de até $12,5 \%$.

PALAVRAS-CHAVE: Geoestatística. Irrigação de precisão. Zea mays L.

\section{REFERENCES}

ALLEN, R. G.; PEREIRA, L. S.; RAES, D.; SMITH, M. Evapotranspiración del cultivo: guías para la determinación de los requerimientos de agua de los cultivos. Roma: FAO, 2006. 323 p. (Riego y Drenaje, Paper 56).

ANDRIOLLI, K. G.; SENTELHAS, P. C. Brazilian maize genotypes sensitivity to water deficit estimated through a simple crop yield model. Pesquisa Agropecuária Brasileira, Brasília, v. 44, n. 7, p.653-660, 2009. https://doi.org/10.1590/S0100-204X2009000700001

ARMINDO, R. A.; BOTREL, T. A.; GARZELLA, T. C. Flow rate sprinkler development for site-specific irrigation. Irrigation Science, Springer Verlag, v. 29, p. 233-240, 2011.

BERGAMASCHI, H.; DALMAGO, G. A.; BERGONCI, J. I.; BIANCHI, C. A. M.; MÜLLER, A. G.; COMIRAN, F.; HECKLER, B. M. M. Distribuição hídrica no período crítico do milho e produção de grãos. Pesquisa Agropecuária Brasileira, v. 39, p. 831-839, 2004. https://doi.org/10.1590/S0100204X2004000900001

BERGAMASCHI, H.; DALMAGO, G. A.; COMIRAN, F.; BERGONCI, J. I.; MÜLLER, A. G.; FRANÇA, S.; PEREIRA, P. G. Déficit hídrico e produtividade na cultura do milho. Pesquisa Agropecuária Brasileira, v. 41, p. 243-249, 2006. https://doi.org/10.1590/S0100-204X2006000200008 
BOX, G. E. P; COX, D. R. An analysis of transformations. Journal of the Royal Statistical Society, v. 26, p. 211-252, 1964.

CERESOLI, L. L.; SOBENKO, L. R.; KREITLOV, B.; ARMINDO, R. A. Variabilidade espacial dos atributos físico-hidráulicos do solo em uma área e estimativa da lâmina de irrigação de precisão. Irriga, Botucatu, Edição Especial, Irrigação, p. 179-190, 2016.

COELHO, A. M.; CRUZ, J. C.; PEREIRA FILHO, I. A. Rendimento de milho no Brasil: chegamos ao máximo? Piracicaba: Potafós, 2003. 12 p. (Informações Agronômicas, 101).

COMUNELLO, E. Aprimoramento do zoneamento agrícola de risco climático do sistema de produção da soja em Mato Grosso do Sul. 2016. Escola Superior de Agricultura "Luiz de Queiroz", Piracicaba, 2016.

CONAB - Companhia Nacional de Abastecimento. Acompanhamento safra brasileira grãos, Safra 2017/18. Sexto levantamento, v. 6, Brasília, Março de 2018.

CRESSIE, N. Spatial prediction and ordinary kriging. Mathematical geology, v. 20, n. 4, p. 405-421, 1988. https://doi.org/10.1007/BF00892986

DIGGLE, P. J.; RIBEIRO JR, P. J. Model-based Geoestatistics. New York: Springer New York, 2007, 229 p.

DOORENBOS, J.; KASSAM, A. H. Efeito da água no rendimento das culturas. Estudos FAO: Irrigação e Drenagem, 33. Campina Grande: UFPB, 1994. 306 p.

HAGHVERDI, A.; LEIB, B. G.; WASHINGTON-ALLEN, R. A.; AYERS, P. D.; BUSCHERMOHLE, M. J. Perspectives on delineating management zones for variable rate irrigation. Computers and Electronics in Agriculture, v. 117, p. 154-137, 2015.

HAGHVERDI, A.; LEIB, B. G.; WASHINGTON-ALLEN, R. A.; BUSCHERMOHLE, M. J.; AYERS, P. D. Studying uniform and variable rate center pivot irrigation strategies with the aid of site-specific water production functions. Computers and Electronics in Agriculture, v. 123, p. 324-340, 2016. https://doi.org/10.1016/j.compag.2016.03.010

KONISHI, S.; KITAGAWA, G. Bayesian information criteria. Information Criteria and Statistical Modeling, p. 211-237, 2008. https://doi.org/10.1007/978-0-387-71887-3_9

KOPP, L. M.; PEITER, M. X.; BEN, L. H. B.; NOGUEIRA, H. M. C. M.; PADRON, R. A. R.; ROBAINA, A. D.; BUSKE, T. C. Simulação da necessidade hídrica e estimativa de produtividade para cultura do milho em municípios do RS. Revista Brasileira de Milho e Sorgo, Sete Lagoas, v. 14, n. 2, p. 235-246, 2015.

KÖPPEN, W. Grundriss der Klimakunde: Outline of climate science. Berlin: Walter de Gruyter, 1931. 388 p.

KRANZ, W. L.; EVANS, R. G.; LAMM, F. R.; O'SHAUGHNESSY, S.A.; PETERS, R.T. A review of mechanical move sprinkler irrigation control and automation technologies. Applied Engineering in Agriculture, ASABE, v. 28, n. 3, p. 389-397, 2012. https://doi.org/10.13031/2013.41494

MARIN, F. R., ANGELOCCI, L. R., NASSIF, D. S. P., COSTA, L. G., VIANNA, M. S., CARVALHO, K. S. Crop coefficient changes with reference evapotranspiration for highly canopy-atmosphere coupled crops. Agricultural Water Management, v. 163, p. 139-145, 2016. https://doi.org/10.1016/j.agwat.2015.09.010

PEGORARE, A. B.; FEDATTO, E.; PEREIRA, S. B.; SOUZA, L. C. F.; FIETZ, C. R. Irrigação suplementar no ciclo do milho "safrinha" sob plantio direto. Revista Brasileira de Engenharia Agrícola e Ambiental, v. 13, n. 3, p. 262-271, 2009. https://doi.org/10.1590/S1415-43662009000300007 
PREVEDELLO, C. L.; ARMINDO, R. A. Física do solo: com problemas resolvidos. 2. ed. revisada e ampliada. Curitiba, Paraná, 2015. 474 p.

R CORE TEAM. R: A language and environment for statistical computing. Vienna: R Foundation for Statistical Computing, 2014.

REICHERT, J. M.; REINERT, D. J.; BRAIDA, J. A. Qualidade dos solos e sustentabilidade de sistemas agrícolas. Revista Ciência e Ambiente, Santa Maria, v. 27, n. 2, p. 29-48, 2003.

RIBEIRO JUNIOR, P. J.; DIGGLE, P. J. geoR: a package from geostatistical analysis. RNEWS, v. 1, n .2, p. $15-18,2001$.

SCHAAP, M. G.; LEIJ, F. J.; VAN GENUCHTEN, M. Th. ROSSETA: A Computer Program for Estimating Soil Hidraulic Parameters with Hierarchical Pedotransfer Function. Journal of Hydrology, v. 251, p. 163-176, 2001. https://doi.org/10.1016/S0022-1694(01)00466-8

SILVA, M. R.; MARTIN, T. N.; ORTIZ, S.; BERTONCELLI, P.; VONZ, D. Desempenho agronômico de genótipos de milho sob condições de restrição hídrica. Revista de Ciências Agrárias, v. 35, n. 1, p. 202-212, 2012.

SIMUNEK, J.; VAN GENUCHTEN, M. Th.; SEJNA, M. The HYDRUS-1D Software Package for Simulating the Movement of Water, Heat, and Multiple Solutes in Variably Saturated Media, Version 3.0, HYDRUS Software Series 1. Riverside: Department of Environmental Sciences, University of California Riverside, 2005.

SOARES, F. C.; PEITER, M. X.; ROBAINA, A. D.; VIVAN, G. A.; PARIZI, A. R. C. Resposta da cultura do milho à variabilidade hídrica em solo sob pivô central. Irriga, Botucatu, v. 17, n. 2, p. 220-233, 2012.

SOUZA, A. P. de; LIMA, M. E. de; CARVALHO, D. F. de. Evapotranspiração e coeficientes de cultura do milho em monocultivo e em consórcio com a mucuna-cinza, usando lisímetros de pesagem. Revista Brasileira de Ciências Agrárias. Recife, v. 7, n. 1, p. 142-149, 2012. 